\title{
EDITORIALS
}

\section{Fighting discrimination and stigma against people with mental disorders}

\author{
EDITORIALI
}

Combattere la discriminazione

e lo stigma verso le persone con disturbi mentali

\author{
ANTONIO LASALVIA, Guest Editor \\ and MICHELE TANSELLA, Editor
}

To calm the imagination of the invalid, so that at least he should not, as hitherto, have to suffer more from thinking about his illness than from the illness itselfthat, I think, would be something It would be a great deal! F. Nietzsche [Thinking about illness from "Daybreak", 1881]

Evidence demonstrates that psychiatric patients suffer not only from the disorder itself, but also - and perhaps principally - from the social and relational consequences produced by the disorder, in terms of marginalization, exclusion, rejection, prejudice, discrimination. The concept which best conveys and summarizes the above processes is "stigma". The concept of stigma was initially developed in social science research to define an "attribute that is deeply discrediting" and that reduces the bearer "from a whole and unusual person to a tainted, discounted one" (Goffman, 1963). This term has subsequently been adopted by social psychiatry to indicate a series of prejudices and negative connotations ascribed to persons with psychiatric problems. Stigma then leads to discrimination and social exclusion. We will not discuss the ethical, political, social and psychological implications connected with the stigmatization processes, nor the dynamics leading to and maintaining such processes. These complex issues require a more detailed discussion which is beyond the scope of this presentation. Nonetheless, it is worthwhile to emphasize that beyond the multiple social negative consequences referred to above, stigmatization processes determine a direct and disrupting impact on the health status of persons with mental disorders, both psychologically and physically. Stigma hinders these persons from accessing appropriate health care. Stigmatisation processes limit these persons
Tranquillizzare l'immaginazione del malato, che almeno non abbia a soffrire, come è accaduto sino ad oggi, più dei suoi pensieri sulla malattia che della malattia stessa, penso sia già qualche cosa.

E non è poco!

F. Nietzsche [Pensieri sulla malattia da "Aurora e Frammenti Postumi”, 1879-1881]

Numerose evidenze dimostrano che le persone affette da un disturbo mentale non soffrono soltanto per il disturbo in sé, ma anche - e forse soprattutto - per le conseguenze sociali e relazionali che il disturbo produce e che si manifestano sottoforma di marginalizzazione, esclusione, rifiuto, pregiudizio, discriminazione. Il termine che forse meglio di tutti è in grado di condensare in un'unica accezione tale condizione è quello di "stigma". Il concetto di stigma, inizialmente sviluppatosi in ambito sociologico per indicare una condizione di discredito permanente che affligge la percezione sociale di una persona impedendone l'accoglimento in un ordinario rapporto sociale (Goffman, 1963), è stato successivamente adottato dalla psichiatria sociale per definire l'insieme di connotazioni negative che vengono pregiudizialmente attribuite alle persone con problemi psichici a causa del loro disturbo e che determinano discriminazione ed esclusione. Non è questa la sede per discutere le implicazioni etiche, politiche, sociali e psicologiche conseguenti ai processi di stigmatizzazione, né per affrontare i temi inerenti alle dinamiche che conducono e mantengono attivi tali processi; tutti questi complessi argomenti meriterebbero una trattazione articolata ed approfondita che ci condurrebbe però lontano dall'obiettivo di questa Presentazione. Vale tuttavia qui la pena ricordare che, al netto dei molteplici danni sociali cui si è fatto cenno sopra, i processi di stigmatizzazione hanno conseguenze dirette e dirompenti sullo 
ability to access a broader set of opportunities through which they may exert their civil rights or reacquire social roles and life skills lost as a consequence of the mental disorder. With this regard, the words used by Susan Sontag to describe the condition of patients with cancer and AIDS, both diseases bearing negative and stigmatising connotations with their own respect, seem perfectly fitting for persons with mental disorders: "the metaphoric trappings that deform the experience of having a disease ...have very real consequences: they inhibit people from seeking treatment early enough, or from making a greater effort to get competent treatment. The metaphor and myths, I am convinced, kill' (Sontag, 1991; p. 99).

Awareness of the importance of stigma related issues has progressively grown in many parts of the world. This is in part due to the work of family and user associations and by the rising patient empowerment movement. Over the last ten years a number of local, national and international campaigns have aimed to raise awareness and understanding of mental illness among the general population and to fight stigma associated with psychiatric disorders. Among international anti-stigma programs, the most important are: The Global Program Against Stigma and Discrimination Because of Schizophrenia-Open the Doors initiated in 1998 by the World Psychiatric Association (WPA) and now implemented in 20 countries worldwide. The Closing the Gap program developed by the World Health Organization in 2002 (World Health Organization, 2002). Among national programs, we highlight the anti-stigma campaign launched in England by the Royal College of Psychiatrists (Crisp, 2004), the campaign launched in Australia by the national charity SANE Australia (Hocking, 2003), and in the USA by the National Alliance for the Mentally Ill (Kommana et al., 1997). In Italy, in 2004 the Ministry of Health launched the First National Campaign for Mental Health "Non $\grave{e}$ diversola da te. Curare i disturbi mentali si può, nessun pregiudizio, nessuna esclusione" ["He/She is not different from you. Treating mental disorders is possible, no prejudices, no exclusion"] (see the volume edited by Cassano et al., 2001); a communication campaign against stigma and discrimination was initiated in 2006 by the same Ministry through the development of a website (http://www.campagnastigma.it/).

Over the same time frame, scientific interest in the stigma and discrimination associated with mental illness experienced parallel growth. This resulted in an increase in the number of research groups involved in the field and the production over the last years of a large number of technical and popular publications. For example, in one of the most recent and comprehensive reviews available on stato di salute, sia psichica che fisica, delle persone con disturbi mentali, perché tendono ad allontanarli dai circuiti attraverso i quali possono ricevere cure ed assistenza specialistica ed esercitare i loro diritti di cittadini, riacquistando ruoli ed abilità persi dopo la comparsa dei disturbi. A tale riguardo, ci sembrano molto calzanti anche per le persone affette da disturbi psichici le parole a suo tempo utilizzate da Susan Sontag per i malati di cancro ed AIDS, patologie entrambe portatrici di connotazioni negative e a loro modo stigmatizzanti: “... più di una volta le bardature metaforiche che deformano l'essere ammalati...hanno conseguenze reali: impediscono ai malati di cercare la terapia con sufficiente tempestività o di fare uno sforzo maggiore per sottoporsi ad una terapia adeguata. Le metafore e $i$ miti... uccidono" (Sontag, 1988; p. 101).

La consapevolezza dell'importanza delle problematiche connesse a questo tema è andata progressivamente crescendo in varie parti del mondo, grazie anche alla spinta delle associazioni di familiari ed utenti e dei nascenti movimenti di empowerment, tanto che negli ultimi 10 anni sono state avviate - su base locale, nazionale e sovranazionale - numerose campagne di sensibilizzazione dell'opinione pubblica verso le tematiche connesse alla salute mentale e di lotta allo stigma. Basti, a tal riguardo, ricordare il programma internazionale Fighting Stigma and Discrimination because of Schizophrenia-Open the Doors, lanciato nel 1998 dalla World Psychiatric Association (1998) ed implementato in 20 nazioni del mondo, oppure il programma internazionale antistigma Closing the Gap dell'Organizzazione Mondiale della Sanità (World Health Organization, 2002), oppure, su base nazionale, il programma avviato dal Royal College of Psychiatrists in Inghilterra (Crisp et al., 2004), quello promosso dall'organizzazione di volontariato SANE in Australia (Hocking, 2003), e quella lanciata dall'organizzazione degli utenti National Alliance for the Mentally Ill in USA (Kommana et al., 1997). Per quanto riguarda il nostro Paese, nel 2004 è stata promossa su iniziativa del Ministero della Salute la Prima Campagna Nazionale per la Salute Mentale "Non è diverso/a da te. Curare i disturbi mentali si può, nessun pregiudizio, nessuna esclusione" (vedi il volume curato da Cassano et al., 2001); e nel 2006 è stato avviato un programma di comunicazione contro il pregiudizio in salute mentale con l'apertura di un sito web curato dallo stesso Ministero (http://www.campagnastigma.it/).

Parallelamente, è andato crescendo l'interesse del mondo scientifico per i temi inerenti lo stigma, cui ha fatto seguito nello stesso arco di tempo la moltiplicazione dei gruppi di ricerca impegnati nel settore e la conseguen-

Epidemiologia e Psichiatria Sociale, 17, 1, 2008 
stigma associated with mental illness, 164 citations (from 2002 to mid-2005), including books and journal articles were selected (Aichenberger \& Sartorius, 2006). Our Journal felt the need to contribute to the ongoing debate and therefore dedicated the first issue of 2001 to stigma associated with mental illness (Angermeyer \& Schulze, 2001; Link, 2001; Warner, 2001).

Despite the growing amount of resources and energies employed in mental health promotion initiatives and antistigma programs, research evidence and clinical practice indicate that in many parts of the world, including western countries, the social image and the integration in the community of patients suffering from mental disorders are still very problematic (Angermeyer \& Matschinger, 2005; Stuart, 2006). Despite the many achievements that have taken place in both mental health care delivery and psychiatric research, significant percentages of people at risk of developing a psychiatric disorder experience barriers to access specialist mental health services and many patients suffering from well-defined psychiatric conditions do not receive the care they need (Alonso et al., 2007; Wang et al., 2007). New and probably more subtle and insidious forms of discrimination and exclusion have wormed their way into society, exacting their dangerous impact on the more vulnerable and fragile groups of the general population. The civil rights of these persons are often neglected and community services do not always include, among their programmes, evidence-based activities aiming to remove those barriers that hinder patient recovery (with this latter regard, see the Editorial of Slade \& Hayward, 2007). For all these reasons we believe it is worthwhile and necessary to focus on stigma associated with mental illness, and therefore we again address this topic in the present issue of Epidemiologia e Psichiatria Sociale. We are convinced that it is important to address this topic by adopting an approach which gives - in opposition to some rising confused pseudo-sociological positions - due attention to the evidence that come from the scientific research. This is of paramount importance, since stigma (an intrinsically complex and at the same time vague concept), represents a field with no clear-cut boundaries, where there is always the risk that anybody may feel legitimated to express questionable positions and propose extemporaneous initiatives. And these initiatives, if not based on the good sense of scientific evidence, would lack any impact on the practical ground. Indeed, such anti-scientific initiatives should be considered as a danger, since they contribute to impoverish an health care sector in great financial suffering, such as mental health is, and to reduce potential resources for methodologically sound anti-stigma projects that might be effective. te produzione di una ricchissima pubblicistica sia divulgativa che tecnica. Solo per avere un'idea della dimensione del fenomeno, in una revisione della letteratura sull'argomento relativa al biennio 2002-2005, Marion Aichenberger e Norman Sartorius hanno selezionato ben 164 citazioni tra articoli di riviste, monografie e capitoli di libri (Aichberger \& Sartorius, 2006); e nel solo 2007, attraverso una personale ricerca bibliografica condotta su PubMed inserendo la parola chiave "stigma" incrociata, rispettivamente, con "mental health", "schizophrenia" e "depression", sono stati da noi individuati più di 200 articoli. A questa ondata di interesse non è rimasta insensibile la nostra Rivista, che ha dedicato il primo fascicolo del 2001 proprio alle problematiche relative allo stigma ospitando tre editoriali (Angermeyer \& Schulze, 2001; Link, 2001; Warner, 2001).

Tutto bene quindi? Le cose stanno davvero procedendo come auspicato? Perché affrontare nuovamente un argomento così ampiamente frequentato, col rischio di inflazionare un territorio già sovraffollato? Nonostante l'ingente impegno di risorse e di energie, la ricerca e l'esperienza indicano come in molte parti del mondo, compreso quello occidentale, l'immagine sociale dei pazienti affetti da disturbi mentali e la loro integrazione nelle comunità di appartenenza non siano molto migliori di quanto non fossero vent'anni fa (Angermeyer \& Matschinger, 2005; Stuart, 2006). E questo nonostante i molti progressi che indubbiamente sono stati compiuti nel campo dell'assistenza e della ricerca: quote rilevanti della popolazione a rischio di sviluppare un disturbo psichico presentano notevoli difficoltà di accesso ai servizi specialistici (Alonso et al., 2007; Wang et al., 2007); molte persone con disturbi conclamati non ricevono l'assistenza di cui necessitano; nuove (e forse più subdole) forme di discriminazione ed emarginazione sembrano insinuarsi nella società, colpendo le fasce più fragili della popolazione, come i pazienti psichiatrici; i diritti civili di queste persone vengono spesso ignorati ed i servizi psichiatrici territoriali non sempre includono, tra le loro attività, le iniziative evidence-based atte a rimuovere le barriere che ostacolano la ripresa (il recovery - si veda l'Editoriale di Slade \& Hayward, 2007). Forse per tutti questi motivi vale ancora la pena, anzi è necessario, tornare sull'argomento e conviene farlo in maniera problematica, sobria e, come tradizione nello stile di EPS, attenta alle evidenze che provengono dal mondo della ricerca scientifica. Perché - e questo pensiamo vada sottolineato con chiarezza - quello dello stigma rappresenta un terreno potenzialmente scivoloso, dai confini non ben delimitati, all'interno del quale ciascuno può sentirsi legittimato ad esprimere posizioni $\mathrm{e}$ proporre iniziative, che se non sostenute dal "buon senso" 
Unfortunately, some confusing and poorly drafted initiatives - expensive, heavily promoted, but lacking any firm evidence base - have been implemented over the last years, particularly in Italy.

This issue of Epidemiologia e Psichiatria Sociale contains three Editorials and a Special Article dealing with stigma towards people with mental illness. All contributions adopted an approach which gave specific emphasis to scientific data. We invited three of the world's prominent experts in the field of stigma who are currently involved with a multisite, international study, the International Study of Discrimination and Stigma Outcomes (INDIGO), to write these contributions. INDIGO - in which our WHO Collaborating Centre for Research in Mental Health in Verona also took part as a collaborating site - is the first large-scale international project on self-perceived stigma, which explores how stigma and discrimination affect the lives of people with of schizophrenia, from the point of view of service users themselves.

In the first editorial, Christoph Lauber - Professor of Psychiatry at the Division of Psychiatry, University of Liverpool - presents a critical overview of the literature on stigma-related issues and highlights strengths and weaknesses (Lauber, 2008). The author first defines and differentiates the concepts of "stereotypes", "prejudices", "discrimination" and "stigmatisation", terms which are often improperly used synonymously. He then reviews the main results of studies investigating the attitudes (and the prejudices) of the general population towards people with mental illness. He concluded that more research is needed on those groups that have more intensive and crucial contacts with psychiatric patients. One alarming aspect emerges when Lauber highlights findings from recent studies conducted in Zurich (Lauber et al., 2004; 2006) on a group of people in daily contact with people with mental illness, namely psychiatric professionals. These studies surprisingly found that attitudes and prejudices of mental health professionals towards people with mental illness did not differ from those found in the general population. Particularly alarming is that among the different professional categories, prejudices and stereotypes were highest among psychiatrists! These findings have also been reported in studies conducted in different cultural contexts (Jorm et al., 1999; Ücok et al., 2004). A recent review on this issue outlined that the relationships between stigma and the psychiatric profession are somewhat complex and its interpretation remains controversial (Schulze, 2007). Lauber dedicates specific attention to the effectiveness and the practical implications of anti-stigma campaigns, openly admitting that the results with this delle evidenze, rischiano di tradursi in operazioni estemporanee, prive di ricadute effettivamente utili e verificabili, che rischiano di depauperare le finanze di un settore, come quello della salute mentale, già in sofferenza e sottrarre risorse a progetti dotati di maggiore solidità di impianto. E, purtroppo, alcune iniziative di questo tipo, anche costose, tanto propagandate quanto completamente prive di verifiche di efficacia, non sono mancate.

Questo numero di Epidemiologia e Psichiatria Sociale ospita tre Editoriali e uno Special Article che affrontano con lo spirito summenzionato il tema dello stigma. Abbiamo invitato per gli Editoriali tre tra i maggiori esperti mondiali del settore, che hanno partecipato ad uno studio multicentrico internazionale da poco terminato, l'International Study of Discrimination and Stigma Outcomes (INDIGO), cui ha preso parte anche il nostro Centro OMS di Ricerca sulla Salute Mentale. L'INDIGO rappresenta il primo progetto internazionale sullo stigma autopercepito che sia stato mai realizzato, nel quale è stata esplorata la percezione soggettiva dalle persone con schizofrenia riguardo alle barriere da essi incontrate a causa dei processi di stigmatizzazione (Thornicroft et al., submitted for publications)

Nel primo Editoriale, Christoph Lauber - Professore di Psichiatria presso la Division of Psychiatry dell'Università di Liverpool - ci propone una lettura critica dell'ampia letteratura relativa allo stigma, evidenziandone pregi e, soprattutto, problematicità (Lauber, 2008). Dopo aver compiuto una opportuna puntualizzazione terminologica dei concetti di "stereotipo", "pregiudizio", "discriminazione" e "stigmatizzazione", accezioni troppo spesso impropriamente utilizzate come sinonimi, Lauber passa in rassegna i risultati degli studi che hanno analizzato il modo di percepire e rappresentarsi le persone con disturbi mentali da parte dalla popolazione generale (con i relativi pregiudizi). L'autore rileva che la ricerca in questo settore mostra alcune carenze, in quanto raramente si è curata di approfondire l'atteggiamento verso i pazienti psichiatrici da parte di coloro che hanno con questi ultimi rapporti più intensi e continuativi. Un aspetto, infatti, preoccupante emerge allorquando Lauber riferisce dei risultati di alcuni studi condotti a Zurigo da lui stesso e dai suoi collaboratori (Lauber et al., 2004; 2006) su particolari gruppi professionali che hanno rapporti quotidiani con le persone con disturbi mentali, nello specifico gli operatori psichiatrici. Questi studi hanno evidenziato in maniera sorprendente che i professionisti della salute mentale sono portatori nei confronti dei pazienti psichiatrici degli stessi pregiudizi diffusi nella popolazione generale e che, tra le varie figure professionali considerate, i più carichi di pregiudizi e stereotipi sembrano essere proprio gli psi- 
respect are not encouraging. At best, the overall results of anti-stigma endeavours are difficult to measure and interpret. At worst the effect of anti-stigma campaigns are small and short-lived. He specifically points out their inability in determining successful and sustainable behaviour modifications in the target populations. Further research is needed in this area, and the implementation of longer follow-up studies evaluating methodologically sound anti-stigma initiatives focussed on specific target groups are also warranted.

In the second editorial, Graham Thornicroft Professor of Community Psychiatry and head of the Service and Population Research Department at the Institute of Psychiatry, London - examines the complex relationships between stigmatization processes and barriers that limit access to specialist mental health care for people with psychiatric disorders (Thornicroft, 2008). In this context we like to emphasize that Thornicroft has made fundamental contributions to the study of stigma, both theoretically - through the recent publication of a compelling monograph (Thornicroft, 2006), and pragmatically - through the coordination of the INDIGO study (Thornicroft $e t$ al., submitted). Thornicroft starts his editorial by reviewing recent findings on treatment coverage for mental disorders including results from the USA National Comorbidity Survey Replication (Wang et al., 2005). Results demonstrate that worldwide at least two thirds of people suffering from a psychiatric condition received no treatment. On the basis of the reviewed studies, Thornicroft highlights the fact that the entry point into the system of specialist health care for people experiencing a mental disorder is not health agencies but is more often informal caregivers, such as complementary or alternative medical providers or members of the clergy. Among the potential factors that limit access to mental health care, Thornicroft suggests that a major role may be played by anticipated stigma. This is a complex process by which persons experience, at best ambivalence, and at worst deliberate avoidance of treatment and care. This is due to a mixture of feelings including: reluctance in admitting or disclosing their psychiatric problems, shame for their condition, fear of being discriminated because of their psychiatric disorder, fear that others would react with avoidance, or beliefs that psychiatric treatments are ineffective. It is interesting to note that this process may be stronger in rural areas than in towns and large cities. Thornicroft proposes as interpretation that this might be due to the fact that if a person with a mental illness wants to keep personal information confidential, this is probably more difficult in rural communities, whereas it may be easier to remain anonymous in large metropolitan areas. chiatri! Questo dato, in verità piuttosto allarmante, è stato riportato anche da altri studi condotti in contesti diversi (Jorm et al., 1999; Ücok et al., 2004), anche se una recente revisione sull'argomento ha messo in evidenza come il rapporto tra stigma e atteggiamenti stigmatizzanti degli operatori psichiatrici sia piuttosto complesso e di non univoca lettura (Schulze, 2007). Particolare attenzione Lauber dedica, infine, all'efficacia e alle ricadute pratiche delle campagne anti-stigma, non nascondendo una certa delusione riguardo agli esiti di tali iniziative, che nel migliore dei casi sono di incerta interpretazione, nel peggiore denotano una scarsa tenuta sul medio-lungo periodo, in particolare riguardo alle capacità di produrre reali modifiche nei comportamenti dei destinatari. Si rendono pertanto necessari studi a lungo termine per valutare l'effetto nel corso del tempo di campagne anti-stigma maggiormente incisive e metodologicamente più solide.

Nel secondo Editoriale, Graham Thornicroft Professore di Psichiatria di Comunità presso l'Health Service and Population Research Department dell'Istituto di Psichiatria di Londra - prende in analisi il complesso rapporto esistente tra i processi di stigmatizzatone e gli ostacoli che le persone con disturbi mentali incontrano nell'accedere alle cure specialistiche (Thornicroft, 2008). Ci piace ricordare che Thornicroft ha fornito al tema in oggetto un contributo fondamentale sia dal punto di vista teorico, con la recente pubblicazione di un importante volume (Thornicroft, 2006), che sul versante empirico, attraverso il coordinamento del precedentemente citato progetto INDIGO (Thornicroft et al., submitted for publication). Passando in rassegna alcuni dati forniti dallo studio replicativo del National Comorbity Survey statunitense, che evidenzia come solo un terzo delle persone che sperimentano un disturbi psichico riceve un qualche tipo di aiuto (Wang et al., 2005), Thornicroft fa notare che la porta di accesso alle cure specialistiche per le persone che richiedono una consultazione per problemi psichiatrici non sia costituita dai servizi sanitari, ma da interlocutori per così dire "informali", rappresentati in buona misura da operatori ecclesiastici e membri del clero. Tra le molteplici ragioni che rendono difficile richiedere un' adeguata assistenza psichiatrica, un ruolo di primo piano è senz'altro giocato da quel processo definito come stigma anticipatorio, che comprende un insieme di stati d'animo ed atteggiamenti nel paziente caratterizzati da difficoltà ad ammettere a sé stessi di avere un problema psicologico, vergogna legata a tale consapevolezza, paura di essere tenuti a distanza dagli altri, scarsa fiducia nell'efficacia delle terapie psichiatriche. È interessante osservare come la riluttanza da parte dei potenziali pazienti ad accedere alle cure psichiatriche 
In the third editorial, Richard Warner - Professor of Psychiatry and Anthropology at the University of Colorado (USA) - deals with problems related to the strategies adopted when implementing anti-stigma projects (Warner, 2008). The author provides a series of practical guidelines, based on the experience of two recent successful anti-stigma initiatives in Calgary (Canada) and Boulder (USA) and performed within the broader framework of WPA Programme Fighting Stigma and Discrimination because of Schizophrenia. These projects are innovative since they apply a new tool, social marketing, which was successfully used in some public health campaigns around the world including AIDS prevention and smoking cessation programs. Warner gives more details on social marketing in his editorial.

According to the author, methodologically sound antistigma initiative should include a series of key steps: 1) establish a multidisciplinary local action committee (including mental health professionals, consumers (service-users), family members, prominent local citizens, such as legislators, media professionals), whose aim is to plan and implement the project and to target the project to the specific needs of the local community; 2) select a well-defined social target group to which the anti-stigma campaign should be addressed (Warner suggests that it is inadvisable to target the general population because there is no evidence of effectiveness); 3) develop an action plan that includes specific goals and objectives for each target group; the goals might include, in increasing order of difficulty: a) developing awareness, b) increasing knowledge, c) changing attitudes, d) changing behaviour. He emphasises that project objectives should be measurable and achievement of goals should be quantifiable. In addition, Warner provides an overview of the advantages of targeting anti-stigma programmes on high school students (the popularity of this target group has less to do with the likelihood that students will stigmatise people with mental illness and more to do with their accessibility and the opportunity to influence the attitudes of a younger generation), and on criminal justice personnel, such as police officers (since they are often involved, along with mental health professionals, in the pathway to psychiatric care, particularly in cases of emergency). The last part of the editorial deals with the complex relationship between stigma and potentially stigmatising messages from the media. Warner concludes that anti-stigma initiatives should strongly lobby news and entertainment media to exclude negative portrayals of people with mental illness.

The special article has been written by two authors from the Department of Psychiatry at Leipzig University, which has been one of the first teams in the world involved in sia maggiore nelle piccole comunità rurali, dove in pratica tutti si conoscono, rispetto alle grandi città dove la condizione di anomia metropolitana rende tale percorso meno problematico.

Nel terzo Editoriale, Richard Warner - Professore di Psichiatra ed Antropologia presso l'Università del Colorado (USA) - affronta il delicato problema delle strategie da adottare allorquando si intenda implementare una iniziativa anti-stigma (Warner, 2008). L'autore fornisce una serie di linee-guida pratiche, basate su precedenti esperienze di successo realizzate a Calgary (Canada) ed a Boulder (USA) nell'ambito del Progetto della WPA Fighting Stigma and Discrimination because of Schizophrenia, e che si richiamano dal punto di vista strategico alle tecniche di marketing sociale utilizzate, ad esempio, nelle campagne internazionali di prevenzione dell'AIDS o di lotta al fumo da tabacco. Un'iniziativa anti-stigma metodologicamente fondata deve prevedere una serie di componenti-chiave, che possono essere così sintetizzate: 1) la costituzione di comitati locali multidisciplinari (a cui devono prendere parte, tra gli altri, professionisti della salute mentale, utenti, familiari, personalità istituzionali ed operatori dei media) che hanno lo scopo di predisporre e pianificare il progetto e modularlo rispetto alle specifiche esigenze della comunità locale; 2) la selezione di uno specifico gruppo sociale target, destinatario privilegiato dell'iniziativa anti-stigma (viene fortemente sconsigliata l'adozione di iniziative che abbiano come target la popolazione generale, in quanto non supportate da evidenze scientifiche); 3) lo sviluppo di un preciso piano d'azione, disegnato su misura rispetto alle specifiche caratteristiche del gruppo target; il piano dovrebbe porsi un ben preciso obiettivo finale che, in ordine crescente di complessità, potrebbe essere rappresentato da: a) lo sviluppo della consapevolezza riguardo al problema, b) l'aumento delle conoscenze sul problema, c) il cambiamento dell'opinione o del punto di vista riguardo al problema, d) la modifica del comportamento. È importante sottolineare - e questo rappresenta un passaggio importante - che gli obiettivi oggetto d'intervento debbono essere misurabili, così come deve essere quantificabile l'eventuale raggiungimento degli stessi. Warner dedica spazio particolare alla discussione di quelli che rappresentano i principali gruppi target delle campagne antistigma, vale a dire gli studenti della scuole (in quanto rappresentano una popolazione agevolmente raggiungibile dal punto di vista pratico e dotata di maggiore recettività rispetto a messaggi che possono più facilmente tradursi in comportamenti "virtuosi"), e gli operatori delle forze di polizia (che si trovano spesso a gestire in qualità di primo filtro quelle situazioni di emergenza e/o allarme sociale

Epidemiologia e Psichiatria Sociale, 17, 1, 2008 
research on stigma related issues. In this article Georg Schomerus and Mathias C. Angermeyer expand the analysis outlined by Thornicroft (2008) on the relationship between stigma and pathway to mental heath care and provide a theoretical framework on how stigma could affect help-seeking (Schomerus \& Angermeyer, 2008). The authors identify three critical levels where discrimination may hinder help-seeking in those seeking help for mental disorders: structural, individual, and discrimination qua self-stigmatisation. Structural discrimination describes the negative consequences for the members of such a group that result from the imbalances and injustice inherent in social structures, political decisions and legal regulations. Examples would include insufficient coverage of mental health care by health insurances in the USA, or a lack of available mental health services or difficult access to mental health services in many part of the world. Individual discrimination substantially overlaps with anticipated discrimination and refers to a well-formed array of negative consequences that individuals with mental disorder anticipate long before they enter psychiatric treatment. A person considering seeking help for a mental health problem for the first time has not yet been labelled as mentally ill and therefore does not yet belong to the discriminated group of "those" with mental illness. When considering seeing a psychiatrist the person might anticipate being diagnosed as mentally ill and, as a result, fear potential discrimination. Discrimination qua self-stigmatisation occurs when members of a minority group internalise the stigmatising ideas of their social environment and start to believe that they are of less value and will be rejected by most people. Anticipated discrimination and self-stigmatisation are the main factors that hinder help-seeking in persons with mental disorders. Stigma research should focus on these factors in order to develop appropriate intervention strategies. An extremely important limiting factor in the decision on whether to seek help from a mental health service is "mental health literacy" (Jorm, 2000). This is broadly defined as the ability of a person to recognise specific disorders or different types of psychological distress, to know what professional help is available and to seek appropriate help (i.e. those who recognize their condition as depression, are more likely to seek help quickly, calling on a psychiatrist and taking antidepressants). Information campaigns aiming to promote better understandings of mental health issues among the general public are based on these assumptions. The main limitation of this approach rests on the fact that the relationship between knowledge about mental illness, help-seeking intention and actual helpseeking is not always straightforward and needs further exploration (Jorm et al., 2000). Determinants of help- che vedono coinvolte persone in scompenso psicopatologico). Le riflessioni finali di Warner sono dedicate al ruolo cruciale giocato dai media nella diffusione di messaggi ad alto impatto emotivo, a loro volta forti induttori di comportamenti stigmatizzanti, ed alla necessità di impiegare gli operatori della comunicazione come alleati nelle campagne anti-stigma.

Lo Special Article, infine, è stato curato dal gruppo del Dipartimento di Psichiatria dell'Università di Lipsia, che tra $\mathrm{i}$ primi a livello internazionale si è occupato delle tematiche relative allo stigma. Qui Georg Schomerus e Mathias C. Angermeyer riprendono il tema del rapporto tra stigma e percorsi di cura affrontato da Thornicroft (2008) e lo declinano approfondendo le dinamiche contestuali ed individuali che si sviluppano lungo il tortuoso percorso che dalla consapevolezza del bisogno di aiuto porta alla richiesta dello stesso (Schomerus \& Angermeyer, 2008). Gli Autori individuano tre punti critici a livello dei quali i processi di discriminazione possono esercitare il ruolo di ostacolo sul percorso che conduce alla richiesta di aiuto: la discriminazione strutturale, la discriminazione individuale e l'autodiscriminazione. La discriminazione strutturale si riferisce alle conseguenze negative che gruppi svantaggiati debbono subire a causa di squilibri inerenti determinate strutture sociali, decisioni politiche e norme di legge (esempi di tale forma discriminatoria possono essere considerati l'insufficiente copertura previdenziale per le spese sanitarie prevista delle compagnie assicurative americane per le persone con disturbi mentali, o la scarsa disponibilità ed accessibilità di servizi di salute mentale in molti Paesi del mondo). La discriminazione individuale è legata al timore da parte delle persone che sperimentano un disturbo mentale di essere trattate in maniera differente e con valenze negative proprio da parte di coloro a cui si rivolgeranno per chiedere aiuto (quindi si configura come paura di essere potenziale oggetto di discriminazione, concetto sovrapponibile al già citato di stigma anticipatorio). L'autostigmatizzazione rappresenta l'esito di un processo cognitivo che l'individuo stesso compie e che fa sì che un determinata persona interiorizzi pregiudizi e atteggiamenti negativi della comunità in cui vive e finisca per considerare sé stesso, allorquando si trova nella condizione di chiedere aiuto per un problema psichiatrico, quale membro del gruppo discriminato, con conseguente abbassamento del livello di autostima e del valore di sé. Stigma anticipatorio e autostigmatizzazione sembrano essere $i$ fattori che maggiormente condizionano la decisione di cercare aiuto da parte delle persone che soffrono di un problema psichiatrico, e rappresentano i due obiettivi principali sui quali la ricerca dovrebbe concentrare la pro- 
seeking for mental disorders are very complex and more research is needed in this field, particularly on understudied groups, such as patients with substance abuse or patients in their first episode of psychosis.

In conclusion, the underlying theme linking the four contributions published in this issue of EPS is the awareness that the fight against stigma is a complex endeavour, with multifaceted implications, and requires the involvement of multiple subjects on different levels. Such a fight needs less rhetoric and more substance: this latter quality may be reached through the adoption of an open-minded approach, able to integrate both experiences (critically evaluated) and, above all, evidence coming from scientific research (Thornicroft \& Tansella, in press). Finally, the fight against stigma and research on stigma related issues is an endeavour which requires continuous resources and "needs a political backup in times where biological aspects in psychiatry have much higher priority than social ones" (Lauber, 2008). The fight against stigma and discrimination is too important to leave it only to some of the multiple subjects involved (i.e. only to psychiatrics), expecially if they are not sufficiently familiar with the scientific method.

Acknowledgements. We thank Dr. Jennifer Randall for helping revise the English version of the manuscript.

\section{REFERENCES}

Aichenberger M. \& Sartorius N. (2006). Annotated Bibliography of Selected Publications and other Material related to Stigma and Discrimination. An Update for the Years 2002 to 2006. World Psychiatric Association: New York.

Alonso J., Codony M., Kovess V., Angermeyer M. C., Katz, S. J., Haro J. M., de Girolamo G., De Graaf R.O.N., Demyttenaere K., Vilagut G., Almansa J., Pierre Lépine J. \& Brugha T. (2007). Population level of unmet need for mental healthcare in Europe. British Journal of Psychiatry 190, 299-306.

Angermeyer M.C. \& Matschinger H. (2005). The stigma of mental illness in Germany: a trend analysis. International Journal of Social Psychiatry 51, 276-284.

Angermeyer M.C. \& Schulze B. (2001). Reducing the stigma of schizophrenia: understanding the process and options for interventions. Epidemiologia e Psichiatria Sociale 10, 1-7.

Cassano G.B., Dell'Acqua G., Garattini S., Maj M., Morosini P.L., Muggia E., Munizza C., Racagni G. \& Tansella M. (Eds.) (2001). La Salute Mentale. Contro il Pregiudizio il Coraggio delle Cure, pp. 1142. Il Pensiero Scientifico Editore: Roma.

Crisp A., Cowan L. \& Hart D. (2004). The college's anti-stigma campaign, 1998-2003. A shortened version of the concluding report. Psychiatric Bulletin 28, 133-136.

Goffman E. (1963). Stigma: Notes on the Management of Spoiled Identity. Prentice Hall: Englewood Cliffs, New Jersey (trad. it.: Stigma: l'Identità Negata, Giuffrè, Milano, 1983).

Hocking B. (2003). Reducing mental illness stigma and discriminationeverybody's business. Medical Journal of Australia 178, Suppl. 5, 47-48.

Jorm A.F. (2000). Mental health literacy - Public knowledge and beliefs about mental disorders. British Journal of Psychiatry 177, 396-401. pria attenzione al fine di mettere a punto strategie di intervento specifico. Così come estremamente importante quale fattore limitante nella decisone di consultare un servizio specialistico risulta essere la cosiddetta "mental health literacy" (Jorm, 2000), che potrebbe essere tradotta come "alfabetizzazione sui problemi di salute mentale": essa consiste nella capacità di riuscire a riconoscere determinati stati emotivi come patologici, attribuire grossolanamente gli stessi ad una categoria psichiatrica ed identificare come potenziale fonte di aiuto i servizi specialistici (ad es. tanto più una persona riconoscerà determinati sintomi come riconducibili alla depressione, tanto più sarà pronta a considerare l'idea di chiedere aiuto e magari dichiararsi disponibile ad iniziare una terapia antidepressiva). Su questi presupposti si fondano i programmi informativi sulle problematiche psichiatriche che dovrebbero, negli auspici dei promotori, aumentare il grado di conoscenza dei disturbi psichiatrici e delle terapie efficaci disponibili. Il limite maggiore di questo approccio, tuttavia, risiede nel fatto che una cosa è riconoscere un problema e sapere quello che teoricamente si dovrebbe fare, altra cosa è dare corso a queste conoscenze con un comportamento conseguente nel momento in cui il problema effettivamente si manifesta (Jorm et al., 2000). I processi che conducono alla richiesta di aiuto sono naturalmente molto complessi e richiedono ulteriori approfondimenti, condotti magari su gruppi di pazienti non sufficientemente studiati come i pazienti con disturbi da sostanze e quelli all'esordio psicotico.

In conclusione, il filo rosso che sembra tenere assieme i quattro contributi presentati in questo numero di EPS è quello di considerare la lotta allo stigma una impresa complessa, dalle ricadute altrettanto articolate, che necessita dell'azione di molteplici soggetti e su piani di intervento differenti; tale lotta ha bisogno di meno retorica e molta concretezza, qualità quest'ultima che può derivare soltanto dall'adozione di un approccio aperto al nuovo, ma che sia in grado di utilizzare non solo le esperienze (valutate in modo critico), ma anche e soprattutto le evidenze che provengono da ricerche condotte in modo rigoroso (Thornicroft \& Tansella, in press); la lotta allo stigma e la ricerca ad essa connessa è, infine, un'impresa che ha continuamente bisogno di essere alimentata ed ha bisogno di un forte "sostegno politico in un periodo come il nostro in cui gli aspetti biologici della psichiatria sembrano avere maggiore priorità rispetto a quelli sociali" (Lauber, 2008). La lotta allo stigma e alla discriminazione è insomma una impresa troppo importante per essere lasciata in mano solo ad alcuni dei molteplici soggetti coinvolti (ad esempio, solo agli psichiatri), soprattutto se essi non hanno sufficiente familiarità con il metodo scientifico. 
Jorm A.F., Korten A.E., Jacomb P.A., Christensen H. \& Henderson S. (1999). Attitudes towards people with a mental disorder: a survey of the Australian public and health professionals. Australian and New Zealand Journal of Psychiatry 33, 77-83.

Jorm A.F., Medway J., Christensen H., Korten A.E., Jacomb P.A. \& Rodgers B. (2000). Attitudes towards people with depression: effects on the public's help-seeking and outcome when experiencing common psychiatric symptoms. Australian and New Zealand Journal of Psychiatry 34, 612-618.

Kommana S., Mansfield M. \& Penn D.L. (1997). Dispelling the stigma of schizophrenia. Psychiatric Services 48, 1393-1395.

Lauber C. (2008). Stigma and discrimination towards people with mental illness - a critical appraisal. Epidemiologia e Psichiatria Sociale $17,10-13$.

Lauber C., Anthony M., Ajdacic-Gross V. \& Rössler W. (2004). What about psychiatrists' attitude to mentally ill people? European Psychiatry 19, 423-427.

Lauber C., Nordt C., Braunschweig C. \& Rössler W. (2006). Do mental health professionals stigmatise their patients? Acta Psychiatrica Scandinavica 113, Suppl. 429, 51-59.

Link B.G. (2001). Stigma: many mechanisms require multifaceted responses. Epidemiologia e Psichiatria Sociale 10, 8-11.

Schomerus G. \& Angermeyer M.C. (2008). Stigma and its impact on help-seeking for mental disorders: what do we know? Epidemiologia e Psichiatria Sociale 17, 31-37.

Schulze B. (2007). Stigma and mental health professionals: a review of the evidence on an intricate relationship. International Review of Psychiatry 19, 137-155.

Slade M. \& Hayward M. (2007). Recovery, psychosis and psychiatry: research is better than rhetoric. Acta Psychiatrica Scandinavica 116, $81-83$.

Sontag S. (1988). AIDS and its Metaphors. Farrar Straus \& Giroux Gordonsville, Virginia, USA (Trad. it. Malattia come metafora. AIDS e cancro, Einaudi, Torino, 1992)
Stuart H. (2006). Mental illness and employment discrimination. Current Opinion in Psychiatry 19, 522-526.

Thornicroft G. (2006). Shunned. Discrimination against People with Mental Illness. Oxford University Press: Oxford.

Thornicroft G. (2008). Stigma and discrimination limit access to mental health care. Epidemiologia e Psichiatria Sociale 17, 14-19.

Thornicroft G. \& Tansella M. (in press). Better Mental Health Care. Cambridge University Press: Cambridge.

Thornicroft G., Brohan E., Rose D., Sartorius N. \& the INDIGO Study Group (submitted for publication). Global pattern of anticipated and experienced discrimination against people with schizophrenia.

Ücok A., Polat A., Sartorius N., Erkoc S. \& Atakli C. (2004). Attitudes of psychiatrists toward patients with schizophrenia. Psychiatry and Clinical Neurosciences 58, 89-91.

Wang P.S., Lane M., Olfson M., Pincus H.A., Wells K.B. \& Kessler R.C. (2005). Twelve-month use of mental health services in the United States: results from the National Comorbidity Survey Replication. Archives of General Psychiatry 62, 629-640.

Wang P.S., Aguilar-Gaxiola S., Alonso J., Angermeyer M.C., Borges G., Bromet E.J., Bruffaerts R., de Girolamo G., de Graaf R. \& Gureje O. (2007). Use of mental health services for anxiety, mood, and substance disorders in 17 countries in the WHO world mental health surveys. Lancet 370, 841-850.

Warner R. (2001). Combating the stigma of schizophrenia. Epidemiologia e Psichiatria Sociale 10, 12-17.

Warner R. (2008). Implementing local projects to reduce stigma of mental illness. Epidemiologia e Psichiatria Sociale 17, 20-25.

World Health Organization (2002). Close the Gap, Dare to Care. Mental Health Global Action Programme. World Health Organization: Geneva.

World Psychiatric Association(1998). Fighting Stigma and Discrimination because of Schizophrenia. World Psychiatric Association: New York. 